\title{
Makna Simbol dalam Bahasa Tominaa pada Upacara Rambu Solo’ Tana Toraja Singgi'na Torampo Tongkon
}

\author{
Lisda, Wimsje Revlin Palar, Viktory Nicodemus Joufree Rotty \\ Jurusan Pendidikan Bahasa dan Sastra Indonesia, Fakultas Bahasa dan Seni, Universitas Negeri \\ Manado \\ lisdadalle@gmail.com,wimsjepalar@unima.ac.id,viktoryrotty@unima.ac.id
}

\begin{abstract}
Abstrak. Penelitian ini bertujuan untuk menjelaskan tentang makna simbol yang terdapat dalam upacara adat rambu solo' pada masyarakat Tana Toraja, terlebih khusus dalam acara singgi'na torampo tongkon. Adapun metode yang digunakan yakni deskriptif kualitatif, sedangkan untuk teknik pengumpulan data menggunakan teknik studi pustaka, penelitian lapangan, wawancara, dan dokumentasi, serta teknik analisis data berupa deskripsi data, reduksi data, dan pengambilan kesimpulan. Berdasarkan hasil analisis data didapatkan bahwa, terdapat fakta-fakta yang dapat dijadikan sumber pengetahuan bagi masyarakat luas. Peneliti menemukan bahwa adanya simbol dalam upacara adat rambu solo' masyarakat Tana Toraja tidak lepas dari makna yang sangat erat dengan kebudayaan, dimana simbol-simbol dalam upacara rambu solo' ini bermakna tentang status-status atau strata sosial dalam masyarakat Toraja. Strata dalam masyarakat toraja terdiri atas 7 tingkatan dimana tingkatan yang ketujuh menjadi tingkatan yang paling tinggi dan mendapat julukan bangsawan. Adanya singgi' dalam upacara rambu solo' ini dimulai pada tingkatan yang keempat dimana pada tingkatan ini jumlah kerbau yang di korbankan yakni 9 ekor kerbau. Kerbau atau dalam bahasa Toraja disebut tedong menjadi salah satu simbol utama dalam upacara rambu solo' karena menurut masyarakat Toraja kerbau atau tedong ini memiliki arti kebangsawanan, apa lagi ketika kerbau itu masuk dalam kategori kerbau belang atau dalam bahasa Toraja disebut saleko. Adapun simbol-simbol lain dalam upacara adat rambu solo'singgi'na torampo tongkon yakni tongkonan (rumah adat masyarakat toraja), londong (ayam jantan), gayang (keris), rara' (kalung), laya atau tombi (sejenis bendera).
\end{abstract}

Kata Kunci: Makna Simbol, Rambu Solo’, Bahasa Tominaa

\section{PENDAHULUAN}

Simbol merupakan salah satu dari beberapa jenis bahasa kiasan yang kurang populer jika dibandingkan dengan jenis bahasa kiasan lainya diantaranya metafora dan simile. Kata simbol ini pertama kali berasal dari bahasa Yunani, yaitu symbollein, yang memiliki makna sebagai verba yang artinya mencocokkan. Namun dari waktu ke waktu arti mencocokkan dalam konteks tanda atau materai perjanjian tersebut berubah arti menjadi tanda pengenal. Jadi, sesuatu dikenali melalui simbol.

"Shaw (1881:367) menyajikan defenisi simbol sebagai sesuatu yang digunakan untuk, atau dianggap mewakili sesuatu yang lain. Atau lebih khusus lagi, simbol adalah sebuah kata, frasa atau ekspresi lainya yang memiliki makna kompleks yang saling terkait". Dalam pengertian ini simbol dipandang memiliki nilai-nilai yang berbedah dari apa pun yang diwakilinya.

Pemahaman tentang kebudayaan adalah suatu persoalan yang sangat dalam dan luas. "Menurut Harris (Spradley,2007:5) konsep kebudayaan di tampakkan dalam berbagai pola tingkah laku yang dikaitkan dengan kelompok-kelompok masyarakat tertentu, seperti adat (kostum) atau cara hidup masyarakat. Kebudayaan selalu menunjukkan adanya derajat menyangkut tingkatan hidup dan penghidupan manusia. Dengan menciptakan adat, budaya serta lingkungan sosial berbedah-beda yang di tumbuh kembangkan dan diwariskan kepada generasi ke generasi”.

Halmini juga tampak dalam masyarakat Toraja, kebudayaan yang dibina, dikembangkan, diketahui danidiakui pihak lain secara nyata akan menunjukkan adanya proses pewarisan budayam dari leluhuri masyarakat Toraja. Kebudayaan tersebut dibangun berdasarkan asas, prinsip-prinsip, aturan- 
aturan, ketentuan-ketentuan, dan strategi tertentu yang berbasis mitologi, seni, kepariwisataan, dan ritual-ritual adat lainya.

Begitu halnya dengan daerah lain, masyarakat Toraja mempunyai bahasa sendiri yakni bahasa Toraja yang biasa digunakan sebagai talat komunikas di rumah atau pergaulan hidup sehari-hari disamping bahasa Indonesia sebagaimana bahasa nasional. Bahasa Toraja terdiri atas dua jenis bahasa yakni bahasa Toraja biasa yang merupakan bahasa Toraja yang digunakan sebagai bahasa pergaulan sehari-hari dan bahasa Tominaa yang sering digunakan dalam upacara adat Toraja.

Bahasa Tominaa berbedah dengan bahasa Toraja biasa yang digunakan oleh masyarakat Toraja pada umumnya sebagai alat komunikasi sehari-hari. Bahasa tominaa disebut sebagaimana bahasa Toraja tingkat tinggi karena kemampuan untuk menyampaikannya hanya dimiliki oleh orang-orang tertentun saja dan dalam penyampaiannya tidak boleh menyimpang dari situasi atau acara adat yang sedang berlangsung. Tomina $a$ adalah salah satu tokoh adat masyarakati Toraja yang dalam kepercayaan leluhur masyarakat Toraja yang disebut aluk to dolo berfungsi sebagai pendoa dan pemimpin pemberian sesajen. Bahasa tominaa dalah rangkaian bahasa sastra Toraja yang biasanya disampaikan oleh tominaa dalam upacara rambu solo' atau rambu tuka'.Adapun proses upacara ini tidak dilakukan kepada semua masyarakat karena dilihat dari status sosial dalam masyarakat.

\section{METODE}

Penelitian ini menggunakan pendekatan kualitatif yang bersifat deskriptif. Artinya bertujuan untuk menggambarkan hal-hal yang berhubungan dengan keadaan atau status fenomena yang berupa kata-kata tertulis atau lisan dari orang-orang dan perilaku yang diamati (Moleong, 1994:3).

Teknik pengumpulan data dalam penelitian ini, yakni:

\section{Studi pustaka}

Studi pustaka yang dimaksud adalah pengumpulan dan pembacaan berbagai informasi melalui buku-buku, hasil penelitian, website dan situ-situs di internet serta tulisan-tulisan lain yang relevan dengan makna simbol.

\section{Penelitian lapangan}

Penelitian lapangan ini menggunakan teknik wawancara, dimana wawancara merupakan teknik pengumpulan data dan informasi secara mendalam dari informan dengan menggunakan pedoman wawancara guna memperoleh keterangan-keterangan serta penjelasan-penjelasan secara lisan. Berkaitan dengan penelitian ini, maka informan yang diwawancarai adalah para tokoh masyarakat terlebih khusus kepada pemangku-pemangku adat yang sudah terbiasa melibatkan diri dalam upacaraupacara adat Toraja.

\section{Dokumentasi}

Untuk memperkuat dari hasil observasi dan wawancara, peneliti melakukan dokumentasi. Adapun dokumentasi berupa rekaman video, foto, beberapa catatan, dan beberapa rekaman suara dari narasumber. Langkah selanjutnya yaitu menerjemahkan bahasa yang digunakan narasumber ke bahasa Indonesia. Bahasa yang digunakan narasumber yakni bahasa tominaa yang digunakan sebagai bahasa khusus pada setiap upacara adat.

\section{HASIL DAN PEMBAHASAN}

Pelaksanaan tradisi rambu solo' diTana Toraja terbagi dalam beberapa tahap berdasarkan status sosial, yaitu:

\begin{tabular}{|l|l|l|l|l|}
\hline No & Tingkatan & Arti & Status Sosial & Keterangan \\
\hline 1. & tedon tunga' & Satu Kerbau & $\begin{array}{l}\text { Kalangan } \\
\text { Bawah }\end{array}$ & $\begin{array}{l}\text { Dalam tingkatan ini dikatakan kerbau satu karena kerbau yang } \\
\text { di korbankan hanya satu ekor kerbau. }\end{array}$ \\
\hline 2. & tedon tallu & Tiga Kerbau & $\begin{array}{l}\text { Kalangan } \\
\text { Bawah }\end{array}$ & \\
\hline
\end{tabular}




\begin{tabular}{|c|c|c|c|c|}
\hline 3. & tedon lima & $\begin{array}{l}\text { Lima } \\
\text { Kerbau }\end{array}$ & $\begin{array}{l}\text { Kalangan } \\
\text { Menengah }\end{array}$ & \\
\hline 4. & tedon kasera & $\begin{array}{l}\text { Sembilan } \\
\text { Kerbau }\end{array}$ & $\begin{array}{l}\text { Kalangan } \\
\text { Menengah }\end{array}$ & $\begin{array}{l}\text { Dalam tingkatan ini tempat jenazah atau lakkean di tempatkan } \\
\text { di depan rumah, di depan lumbung itu yang menandakan } \\
\text { bahwa orang yang meninggal hanya di potongkan } 9 \text { ekor } \\
\text { kebau. }\end{array}$ \\
\hline 5. & $\begin{array}{l}\text { tedon } \\
\text { sanpulodua }\end{array}$ & $\begin{array}{l}\text { Dua Belas } \\
\text { Kerbau }\end{array}$ & $\begin{array}{l}\text { Kalangan } \\
\text { Menengah }\end{array}$ & $\begin{array}{l}\text { Dalam tingkatan ini jenazah di buatkan tempat diluar rumah } \\
\text { sebelah barat. }\end{array}$ \\
\hline 6. & $\begin{array}{l}\text { tedon sanpulo } \\
\text { annan }\end{array}$ & $\begin{array}{l}\text { Enam Belas } \\
\text { Kerbau }\end{array}$ & $\begin{array}{l}\text { Kalangan } \\
\text { Atas }\end{array}$ & $\begin{array}{l}\text { Pada tingkatan ini jenazah di bawah atau di pasonglok ke luar } \\
\text { kampung kemudian dibuatkan pondok bermotif Toraja dan di } \\
\text { pebabaran dibuatkan juga balak kayan( tempat untuk } \\
\text { membagikan daging yang akan diberikan kepada masyarakat } \\
\text { sekita pesta rambu solo' dan juga pada tingkatan ini orang } \\
\text { yang suda meninggal akan di buatkan patung. }\end{array}$ \\
\hline 7. & $\begin{array}{l}\text { tedon } \\
\text { duanpulo } \\
\text { a'pa? }\end{array}$ & $\begin{array}{l}\text { Dua Puluh } \\
\text { Empat } \\
\text { Kerbau }\end{array}$ & $\begin{array}{l}\text { Kalangan } \\
\text { Atas }\end{array}$ & $\begin{array}{l}\text { Dalam tingkatan ini, tingkatan ketuju menjadi tingkatan yang } \\
\text { paling tinggi karena kerbau yang di korbankan minimal } 2 \text { ekor } \\
\text { kerbau. }\end{array}$ \\
\hline
\end{tabular}

\section{A. Rambu Solo'}

Rambu solo' adalah upacara pemakaman yang berada di Tana Toraja. Upacara ini merupakan adat istiadat yang telah diwarisi oleh masyarakat Toraja secara turun-temurun ini mewajibkan keluarga yang ditinggal mati membuat pesta besar sebagai penghormatan terakhir kepada mendiang yang telah pergi. Rambu solo' juga merupakan upacara yang meriah karena dilangsungkan selama berhari-hari. Dan juga bagi masing-masing golongan masyarakat tentunya upacara ini berbeda-beda. Bila golongan bangsawan meninggal dunia maka jumlah kerbau yang dipotong untuk keperluan acara jauh lebih banyak dibandingkan dengan masyarakat yang bukan keturunan bangsawan.

Pelaksanaan rambu solo' juga identik dengan penyembelihan kerbau dan babi, tetapi yang paling ditonjolkan dalam upacara tersebut adalah penyembelihan kerbau. Kerbau merupakan hal utama yang harus ada dalam upacara ini. Masyarakat juga beranggapan bahwa kerbau adalah kendaraan yang ditunggangi arwah yang sudah meninggal untuk mengantarnya ke surga. Kerbau yang disembelih berkisar puluhan ekor bahkan bisa mencapai ratusan berdasarkan strata sosialnya.

1. Tedong tungga' (kerbau tunggal)

a) Makna inferensial yang terkandung dalam tedong tungga' ialah bermakna satu kerbau atau kerbau tunggal

b) Makna significance ialah bermakna bahwa dalam simbol tedong tungga' ini hanya berlaku bagi kalangan bawah atau dalam masyarakat memiliki strata sosial paling bawah.

c) Makna infensional dalam tahapan ini ialah di katakan tedong tungga' karena kerbau yang dikorbankan dalam tahap ini hanya 1 ekor karena hanya untuk masyarakat kalangan bawah.

2. Tedong tallu (tiga kerbau)

a) Makna inferensial dalam tahapan ini ialah bermakna tiga ekor kerbau

b) Makna significance ialah bahwa kerbau yang di korbankan dalam tingkatan ini ialah 3 ekor kerbau

c) Makna infensionalnya ialah dalam tahapan ini kerbau yang di korbankan hanya tiga ekor kerbau dan masih dalam tahapan untuk masyarakat kalangan bawah.

3. Tedong lima

a) Makna inferensialnya ialah dalam tahan ini dikatakan tedong lima karena kerbau yang di korbankan hanya lima ekor.

b) Makna significance ialah dalam tahapan ini yaitu tahapan tedong lima sudah masuk tahapan untuk kalangan menengah.

c) Makna infensionalnya ialah kerbau yang di korbakan dalam tahapan ini hanya lima ekor dan sudah masuk dalam tahapan masyarakat menengah.

4. Tedong kasera

a) Makna inferensial ialah dalam tahapan ini kerbau yang dikorbankan hanya lima ekor kerbau

b) Makna significance ialah bahwa dalam tahapan ini sama halnya dengan tahapan lima bahwa sudah masuk dalam tahapan bagi kalangan menegah 
c) Makna infensionalnya ialah dalam tahapan ini kerbau yang di korbankan ialah 9 ekor kerbau dan sudah masuk dalam tahapan masyarakat menengah dan juga salah satu ciri khas dari tahapan tedong kasera ini ialah tempat jenazah atau lakkean di tempatkan di depan rumah, di depan lumbung yang menandakan bahwa orang yang meninggal hanya di potongkan 9 ekor kerbau.

5. Tedong sangpula dua

a) Makna inferensial ialah dikatakan tedong sangpulo dua karena dalam tahapan ini kerbau yang di korbankan yaitu 12 ekor kerbau.

b) Makna significance dalam tahapan ini ialah pada tradisi rambu solo' tahapam tedong sangpulo dua sudah masuk dalam tahapan kalangan menengah.

c) Makna infensional ialah dalam tahapan ini kerbau yang dikorbankan yaitu 12 ekorkerbau dan sudah masuk dalam tahapan masyarakat menengah atas dan pada tahapan ini pula jenazah di buatkan tempat di luar rumah sebelah barat.

6. Tedong sangpula annan

a) Makna inferensial dalam tahapan dalam ialah kerbau yang di korbankan dalam tahapan ini yaitu 16 ekor kerbau

b) Makna significance dalam tahapan tedong sangpulo annan yaitu dalam tahapan ini sudah masuk dalam kalangan atas atau kategori bangsawan

c) Makna infensional pada tahapan ini kerbau yang di korbankan yaitu 12 kor kerbau dan orang yang sudah meninggal sudah masuk kategori kalangan atas dan pada tahapan ini memiliki ciri khas bahwa jenazah akan di bawah atau di pasonglok ke luar kampung dan dibuatkan pondok bermotif toraja dan di pebabaran dibuatkan juga balak kayak atau tempat untuk membagi-bagikan danging yang akan diberikan kepada masyarakat yang ada di sekitar pesta. Dan juga juga pada tahan ini jenazah akan dibuatkan patung.

7. Tedong duangpulo akpa'

a) Makna inferensial dalam tahapan ini adalah tedong duangpulo akpa' yang berarti kerbau yang dikorbankan berjumlah 24 ekor kerbau

b) Makna significance dalam tahapan ini adalah dalam tahapan ini masuk dalam tingkatan yang paling tinggi dan masuk golongan bangsawan.

c) Makna infensional dalam tahapan ini yakni dalam tahapan ini kerbau yang di korbankan minimal 24 ekor kerbau dan merupakan status sosial tertinggi dalam upacara rambu solo’.

Berdasarkan penjelasan diatas, dalam tradisi rambu solo' Tana Toraja salah satu tahapan yang dilakukan dalam prosesi rambu solo' adalah untarima to rampo tongko atau penerimaan tamu. Tamu yang hadir dalam upacara tersebut disambut dengan rangkaian kata yang sangat indah yang dinamakan singgi'na toramo tongkon yang di ungkapkan dalam bahasa tominaa.Bahasa tominaa berikut diungkapkan ketika tamu atau kerabat dari keluarga yang meninggal memasuki tempat upacara adat berlangsung dan mereka membuat satu atau tiga baris untuk beriringan menuju ke lantang karampoan (semacam pondok yang dibuat khusus untuk tamu dan keluarga yang datang melayat).

\begin{tabular}{|c|c|c|}
\hline No. & Bahasa Singi'/Tominaa & Arti \\
\hline \multirow[t]{5}{*}{ A. } & $\begin{array}{l}\text { singi' untuk tamu yang hadir di tempat } \\
\text { upacara: } \\
\text { a) mellindomo rara makamban,sola } \\
\text { buku tangsianderan. }\end{array}$ & a) telah datang keluarga besar dari keluarga yang berduka \\
\hline & $\begin{array}{l}\text { b) tu tiumbak diomai pira-pira } \\
\text { ba'bana lemban, pantan dollo' } \\
\text { diomai makamban pentutuan lipu. }\end{array}$ & b) Mereka berasal dai berbagai macam daerah \\
\hline & 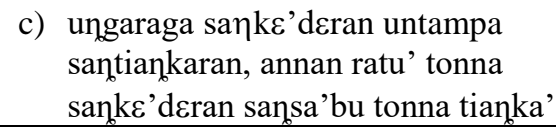 & $\begin{array}{l}\text { c) dan mereka datang dalam jumlah yang sangat banyak } \\
\text { bersama kerabat mereka }\end{array}$ \\
\hline & $\begin{array}{l}\text { d) lako tomakrapu tallan, mairik to } \\
\text { sankaponan ao, }\end{array}$ & d) untuk keluarga yang sedang berduka. \\
\hline & $\begin{array}{l}\text { e) lo’ban-lo'bananni lalan palempe } \\
\text { sanpiakanmi }\end{array}$ & $\begin{array}{l}\text { e) kepada pihak keluaga untuk memberika jalan dan } \\
\text { siapkan termpat bagi mereka }\end{array}$ \\
\hline
\end{tabular}




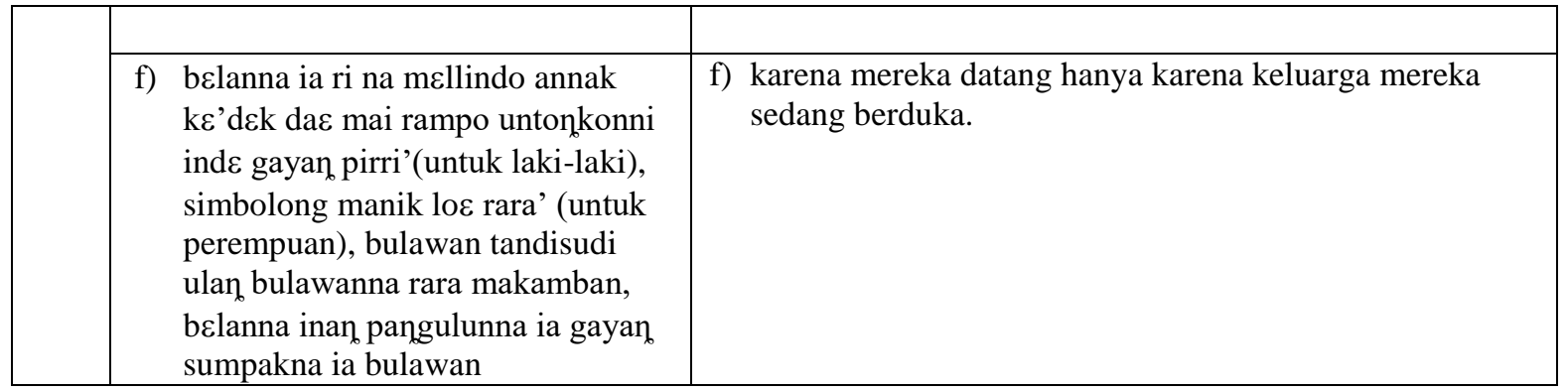

Setelah tamu atau kerabat dari keluarga yang berduka sudah memasuki tempat yang sudah disedikan maka singgi' untuk keluarga pun di lantunkan.

Bahasa tominaa ini di ungkapkan ketika tamu atau kerabat dari keluarga yang meninggal sudah duduk di tempat yang di sediakan kemudian di jamu oleh keluarga yang dibawah oleh to ma'pairuk (yang membawa siri, pinang, rokok, minuman dan kue).

\begin{tabular}{|c|c|c|}
\hline No. & Bahasa Singi'/Tominaa & Arti \\
\hline \multirow[t]{4}{*}{ B. } & $\begin{array}{l}\text { singi' untuk keluarga yang berduka: } \\
\text { a) to ko ta tiro-tiromi lako, } \\
\text { tukatakpatakpai mata }\end{array}$ & a) lihatlah dan sambutlah keluarga besar yang telah datang \\
\hline & $\begin{array}{l}\text { b) na mendadi dappina pa'di' } \\
\text { temmekna rosso inawa }\end{array}$ & $\begin{array}{l}\text { b) yang akan menjadi obat bagi keluarga (menjadi } \\
\text { penghibur). }\end{array}$ \\
\hline & $\begin{array}{l}\text { c) tasitiro lindo mo inde paka- } \\
\text { pakanna gayan, mak urunan na } \\
\text { bulawan yato allo ingnak tuk } \\
\text { kullak pura di boko' turunanna tau } \\
\text { lak la'bi' ossoran dandanan sakka', } \\
\text { to di pangannai kada, todi sedan } \\
\text { bisara, ossoran kada todolo. }\end{array}$ & $\begin{array}{l}\text { c) lihatlah keluarga besar telah berkumpul bersama, } \\
\text { sebagai bukti bahwa mereka sangat menjunjung tinggi } \\
\text { rasa kekeluargaan seperti yang sudah di ajarkan oleh } \\
\text { orang tua. }\end{array}$ \\
\hline & 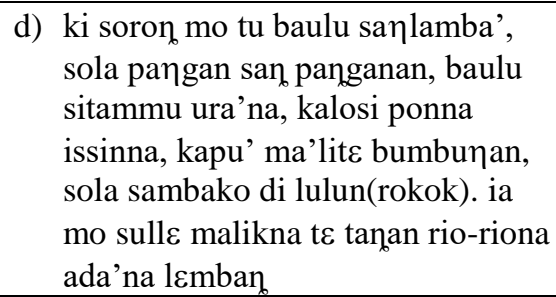 & $\begin{array}{l}\text { d) Kepada pihak keluarga untuk memberikan siri,pinang } \\
\text { dan rokok sebagai tanda menerima keluarga dengan baik } \\
\text { yang akan menjadi penyejuk jiwa/peluluh lara terhadap } \\
\text { pikiran buruk adat lembang. }\end{array}$ \\
\hline
\end{tabular}

\section{B. Simbol Yang Menandakan Status Sosial}

\section{Saleko (Kerbau Belang)}

Saleko atau kerbau belang adalah symbol kebangsawanan. Begitu berharganya kerbau bagi masyarakat Toraja sehingga kerbau dipakai sebagai simbol status sosial seperti yang terlihat pada kutipan berikut:

$$
\begin{aligned}
& \text { rampomo salckona tondok }
\end{aligned}
$$

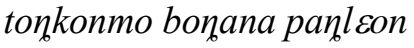

\section{Terjemahan}

Sudah.hadir.salekonya.daerah

Datanglah.bonganya.wilayah

Saleko dalah jenis kerbau belang sedangkan bonga adalah jenis kerbau belang tetapi harganya lebih murah jika dibandingkan dengan saleko. saleko merupakan symbol dari seorang bangsawan atau status sosialnya tinggi. Saleko dipakai untuk menyebut atau menyanjung seorang yang mempunyai kekuasaan dan kekayaan serta pengaruh yang besar dalam masyarakat. Saleko merupakan simbol bangsawan yang berkuasa, kaya dan berpengaruhi karena saleko adalah jenis kerbau belang yang termahal di Toraja yang 
harganya bisa mencapai 750 juta rupiah bahkan ada yang mencapai harga 1M. Karena harganya mahal sehingga hanya orang tertentu mampu membelinya untuk dipersembahkan saat meninggal.

\section{Tongkonan (Rumah Adat Toraja)}

Tongkonan merupakan wadah tempat berkumpulnya para kaum bangsawan Toraja, untuk membicarakan masalah-masalah yang berhubungan dengan adat. Oleh karena karena itu, tidak semua bangunan adat Toraja disebut tongkonan. Tongkonan yang sebenarnya merupakan tempat kaum bangsawan yang memiliki wibawa kepemimpinan, kekuasaan, dan kekayaan. Pada saat penerimaan tamu kaum bangsawan disebut asal-usul tongkonannya sebagai sanjungan dan identitas bangsawan tersebut seperti dalam kutipan berikut:

$$
\begin{aligned}
& \text { todilolloan dao mai tonkonan layuk }
\end{aligned}
$$

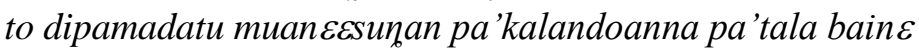

$$
\begin{aligned}
& \text { tonkonan pescoaluk tambakuku }
\end{aligned}
$$

\section{Terjemahan:}

Orang yang mewarisi tongkonan yang agung

Orang yang dihormati kedudukannya baik laki-laki maupuperempuan

Tongkonan pemangku adat yang kuat dan kokoh.

Ungkapan di atas menggambarkan bahwa orang tersebut merupakan seorang yang lahir dari keluarga yang memiliki status sosial yang tinggi dalam masyarakat dan lahir dari sebuah keluarga yang dikenal orang banyak yang mewarisi tongkonan itu secara turun-temurun.Dari tongkonan itu lahir penguasa pemimpin atau pemangku adat yang mempunyai kuasa memerintah dan mengayomi orang banyak yang disebut to parenñe'.

\section{Londong (Ayam Jantan atau Ayam Jago)}

Londong atau disebut pula ayam jago ini pada masyarakat Toraja dilambangkan sebagai lambang kepemimpinan atau kedisiplinan. Dimana ketika ayam ini di pasangi taji dan terlibat dalam pertarungan dengan ayam lain maka ayam jago ini akan berjuang sekuat tenaga sampai mati. Meskipun sudah tidak mampu dan sudah terlihat tidak berdaya lagi karena terkena taji akan tetapi dia masih berusaha untuk berdiri menerjang, dan mengepakkan sayapnya. Selama masih bisa berdiri tidak ada kata menyerah sedikit pun. Bahkan jika sudah terkapar tak berdaya dia masih berusaha untuk berdiri dan akhirnya mati lemas. Ini menyimbolkan keberanian dan semangat pantang menyerah.

Ayam jantan adalah simbol pemberani dan pemimpin yang disiplin.Sama halnya sultan hasanuddi diberi gelar ayam jantan dari timur yang melambangkan seorang pemberani yang tidak kenal lelah dan pantang menyerah. Demikian pula pada acara penerimaan tamu dalam pesta rambu solo', ayam jantan dipakai untuk menyambut dan menyebut pemberani atau pemimpin seperti pada kutipan berikut:

$$
\begin{aligned}
& \text { rampomo londonkila'na padan di panala' } \\
& \text { tu'tunmo saunan la'te lambunna pentutuan lipu sanda kasalle }
\end{aligned}
$$

\section{Terjemahan:}

Sudah datang ayam jago hebat dari daerah Pangala'

Sudah tiba ayam taruhan dari berbagai penjuru wilayah.

Londong atau ayam jago dipakai untuk menyanjung dan menyebut pemberani atau keturunan pemberani yang hadir dalam pesta rambu solo' tersebut. Dari daerah panggala' ( nama kampung di Toraja) misalnya ada seorang pahlawan yang terkenal namanya pong tiku. Pong tiku seorang pahlawan yang gagah perkasa. Dengan berani melawan penjajah belanda yang ingin menguasai Tana Toraja yang lasim dikenal bumi lakipadada.Selama hayat masih dikandung badan, tak ada kata menyerah dia terus berjuang melawan penjajah sampai titik darah penghabisan laksana ayam jago yang perkasa mengepakkan sayapnya, menerjang lawannya tanpa rasa takut dan gentar.

\section{Gayang (Keris), Rara' (Sejenis Kalung)}

Gayang dan rara' bagi masyarakat Torajaadalah benda pusaka yang tidak ternilai harganya. Awalnya gayang dan rara' umumnya dibuat dari emas musri atau setidaknya disepuh dengan emas. Karena terbuat dari emas murni sehingga tidak semua orang bisa membeli dan memilikinya pada saat itu. 
Hanya orang tertentu saja yang mampu yakni dari kalangan bangsawan. Hal inilah yang menyebabkan mengapa gayang dan rara' dipakai untuk menyimbolkan kaum bangsawan. Gayang atau keris adalah simbol laki-laki bangsawan sedangkan rara' simbol perempuan bangsawan.

Demikian dalam penyambutan tamu, kaum bangsawan yang ada di antara rombongan tamu disambut dan disanjung dengan ungkapan berikut:
rampo mananmo muane, takinan gayanna nangala
rampo inde simbolon manikna to merrapu tallan
lokkon loe rara'na pentutuan lipu sanda kasalle
Terjemahan:
Sudah..hadir..seorang..lelaki, pemegang..kerisnya..Nanggala
Sudah..datang..seorang..perempuan..dari..rumpun..keluarga
Perempuan..pemakai..rara'..dari..segala..penjuru..wilayah.

Ungkapan di atas adalah sambutan dan sanjungan terhadap seorang laki-laki bangsawan yang ada di antara rombongan tamu. Bangsawan tersebut berasal dari sebuah kampung yang bernama Nanggala. Laki-laki bangsawan itu disimbolkan gayang atau keris. Di antara rombongan tamu, selain bangsawan laki-laki, terhadap juga bangsawan perempuan. Perempuan itu disimbolkan rara' yakni secaman kalung yang dipakai kaum perempuan, terbuat dari emas. Harganya mahal dan hanya kaum bangsawan yang mampu membelinya pada zaman dulu.Karena bernilai sehingga rara' dipakai untuk menyimbolkan kebangsawanan.

5. Laya atau tombi, merupakan sejenis bendera yang menandakan jumlah kerbau yang di korbankan pada saat upacara adat tersebut.

Pelaksanaan upacara rambuisolo' diiTanaiToraja ternyata.sarat.dengan.simbol secara khusus yang terdapat dalam bahasa tominaa singgi'na torampo tongkon singgi'na torampo tongkon yang merupakan untaiankata puitis yang dipakai untuk menyambut rombongan tamu yang hadir dalam upacara rambu solo'. "Ricoeur menyatakan bahwa bentuk simbol dapat diidentifikasikan dan diklasifikasikan menjadi dua kelompok, yakni simbol verbal dan simbol nonverbal. Simbol verbal adalah simbol-simbol yang berupa bahasa yang dituturkan". Dimana simbol-simbol verbal yang terdapat dalam rambu solo' ini yakni untaian kata-kata puitis yang digunakan untuk menyambut dan menyanjung para tamu atau kerabat keluarga yang telah hadir dalam acara adat tersebut. Dan ketika mereka hendak masuk ke tempat upacara mereka akan di sanjung dengan kata-kata atau dikenal dengansinggi'na torampo tongkon.

Adapun simbol nonverbal dalam upacara adat ini yakni saleko (kerbau belang), tongkonan( rumat adat Toraja), gayang (keris), rara' (jenis kalung), adalah simbol kaum bangsawan, londong (ayam jantan) adalah simbol pemberani. Simbol - simbol ini merupakan simbol yang sangat umum di ungkapkan dan digunakan pada upacara rambu solo' pada acara singgi'na torampo.

Inilah yang menjadi dasar alasan peneliti untuk meneliti makna simbol dalam acara rambu solo' masyarakat Tana Toraja, dengan demikian harapan peneliti semoga penelitian ini bisa bermaanfaat bagi masyarakat luas terlebih khusus bagi masyarakat yang belum mengenal tentang makna-makna yang terkandumg dalam simbol-simbol acara rambu solo' masyarakat Tana Toraja.

\section{KESIMPULAN}

Berdasarkan hasil pembahasan dan penelitian, maka disimpulkan bahwa dalam upacara adat Tana Toraja terdapat berbagai macam simbol-simbol yang menentukan status sosial masyarakat terlebih khusus pada upacara adat Rambu Solo'. Adapun simbol-simbol yang digunakan adalah saleko (Kerbau Belang) Simbol Kebangsawanan, tongkonan (Rumah Adat Toraja), londong (Ayam Jantan atau Ayam Jago)gayang (keris) dan rara' (sejenis kalung). Dan dalam penggunaan singgi' dalam upacara adat Tana Toraja terdapat beberapa tingkatan namun adanya singgi' pada upacara adat ini ada pada tingkat keempat ( tedong kasera), adapun tingkatanya ialah tedong tungga' yang dilaksanakan oleh masyarakat kalangan bawah atau disebut juga tingkat pertama, tedong tallu, tedong lima, tedong kasera, tedong sangpulo annan, untuk tingkat menengah dan duangpulo akpak tedong atau lebih, tingkatan paling atas (sapurandanan, artinya dalam tahap ini kerbau yang di korbankan minimal 24). 


\section{DAFTAR PUSTAKA}

Spradley, James P. 2007. Metode Etnografi. Yogyakarta: Tiara Wacana.

Moleong, Lexy J, 2004, Metodologi Penelitian Kuaitatif, Bandung; Remaja Rosdakaya 